\title{
Identification of duplicates of cassava accessions sampled on the North Region of Brazil using microsatellite markers
}

\author{
Elisa Ferreira MOURA¹, João Tomé de FARIAS NETO², José Edson SAMPAIO³, Diehgo Tuloza DA SILVA4, \\ Girena Fernandes RAMALHO5
}

\begin{abstract}
Duplicates are common in germplasm banks and their identification is needed to facilitate germplasm bank management and to reduce maintenance costs. The aim of this work was to identify duplicates of cassava from a germplasm bank in Eastern Amazon, which had been previously characterized both morphological and agronomically. In order to be genotyped with 15 microsatellite loci, 36 accessions were selected. These accessions were classified into 13 groups of similar morpho-agronomical characteristics. All loci were polymorphic, and 75 alleles were identified, with an average of five alleles per loci and $\mathrm{H}_{\mathrm{E}}=$ 0.66. There were determined 34 pairs of genotypes with identical multiloci profiles and the probability of genetic identity was $1.1 \times 10^{-12}$ with probability of exclusion of $99.9999 \%$. Among these duplicates, there are accessions sampled on different years and places, but with different names and accessions with the same name sampled in different places and years. The study identified genotypes that are grown in different places and that have been maintained over the years by local farmers.
\end{abstract}

KEYWORDS: Manihot esculenta; germplasm; molecular markers

\section{Identificação de duplicatas em acessos de mandioca coletados na Região Norte do Brasil por meio de marcadores microssatélites}

RESUMO

Duplicatas costumam ocorrer em bancos de germoplasma e a sua identificação é necessária para facilitar o manejo dos bancos ativos de germoplasma (BAGs) e diminuir custos de manutençáo. O objetivo deste trabalho foi identificar duplicatas de mandioca determinadas previamente pela caracterização morfo-agronômica, em um BAG da Amazônia Oriental. Foram selecionados 36 acessos que se agrupavam em 13 grupos de similaridade morfo-agronômica para serem genotipados com 15 locos microssatélites. Todos os locos foram polimórficos, sendo obtidos 75 alelos, com média de cinco alelos por loco e $\mathrm{H}_{\mathrm{E}}=$ 0,66 . Foram encontrados 34 pares de genótipos que apresentaram perfis multilocos idênticos e a probabilidade de identidade genética foi de $1,1 \times 10^{-12}$ com probabilidade de exclusão de $99,9999 \%$. Entre essas duplicatas, estão materiais coletados em épocas e locais diferentes, e com diferentes denominaçôes e acessos com o mesmo nome coletados em diferentes locais e anos. O estudo identificou genótipos que vem sendo cultivados em diferentes locais e que vêm sendo mantidos pelos agricultores ao longo dos anos.

PALAVRAS-CHAVE: Manihot esculenta; germoplasma; marcadores moleculares

\footnotetext{
1 Embrapa Amazônia Oriental, Trav. Dr. Enéas Pinheiro s/n caixa postal 48, Belém, Pará CEP: 66095-100. E-mail: elisa.moura@embrapa.br

2 Embrapa Amazônia Oriental, Trav. Dr. Enéas Pinheiro s/n caixa postal 48, Belém, Pará CEP: 66095-100. E-mail: joao.farias@embrapa.br

${ }^{3}$ Embrapa Amazônia Oriental, Trav. Dr. Enéas Pinheiro s/n caixa postal 48, Belém, Pará CEP: 66095-100. E-mail: edson.sampaio@embrapa.br

${ }^{4}$ Universidade Federal do Pará, Campus Universitário do Guamá, Rua Augusto Corrêa,no. 1, Instituto de Ciências Biológicas - Campus Básico, CEP: 66075-110. E-mail: dbiotuloza@hotmail.com

${ }^{5}$ Universidade Federal Rural da Amazônia, Universidade Federal Rural da Amazônia, Avenida Presidente Tancredo Neves, $n^{0}$ 2501, Bairro: Terra Firme Cep: 66.077-530 Caixa Postal: 917, Belém, Pará, Brasil. E-mail: girenaufpa@yahoo.com.br
} 


\section{INTRODUCTION}

Cassava (Manihot esculenta) is an important source of carbohydrates for more than 800 million people around the world, especially in underdeveloped countries. There are reasons to believe that the species domestication has occurred towards the Southern border of the Amazon Basin (Olsen and Schaal 2001; Leotárd et al. 2009). Possibly the North region keeps a great portion of cassava genetic variation, specially due to the diversity of products that local farmers generate from this root.

In Brazil, cassava is grown almost all across its territorial extension, which means the country has genetic variability for adaptation to different environments and climatic conditions. This variability has been maintained on germplasm bank and collections established in different sites of the country. One of them is established on Pará State, the main producer of cassava in Brazil and also known for the diversity of products its population generates from cassava root and even from its leaves. The bases of this germplasm bank are genotypes sampled in properties of familiar farmers from Pará State. At the present, the germplasm bank maintains 470 accessions, including genotypes of 'sweet', 'bitter' and 'sugary'cassava. The accessions have been characterized according to 39 morpho-agronomical characters, established by Fukuda and Guevara (1998), which is followed by the majority of Brazilian germplasm collections and banks. Based on this characterization, some morpho-agronomical similarities have been observed among accessions, including ones with different names and sampled in different places. The identification of duplicates on germplasm banks is interesting to reduce its size, which facilitates its management. Also, it helps the genetic breeding program, since identical genotypes will not be chosen for field trial experiments or for controlled crosses.

The main procedure to identify duplicates is using molecular genotyping, since molecular markers represent a portion of the genome that does not suffer environmental influence. Microsatellite markers, due to high information generated per locus, have been used to identify duplicates on germplasm banks and populations of different species (Robichaud et al. 2006; Irish et al. 2010; van Treuren et al. 2010). Methods of identification that use multiloci profiles of microsatellites are more accurate than the ones based on dominant markers, since genotypes can present a complete coincidence and the probability of casual coincidence can be measured based on allelic frequencies (Paetkau and Strobeck 1994).

Thus, the aim of this work was to genotype cassava accessions previously identified as morpho-agronomically similar with microsatellite markers, in order to verify if they represent duplicates.

\section{MATERIALS AND METHODS}

It was selected 36 accessions from the Germplasm Bank of Embrapa Eastern Amazon, located in Belém, Pará, Brazil. The accessions were morphologically characterized according to Fukuda and Guevara (1998) and they showed similarity. These accessions were divided according to the morphological characterization in 13 groups (Table 1). When samples were being collected, it was decided to maintain the same name given by farmers. The selected accessions were composed of 16 samples of 'sweet' cassava, differentiated by the letter ' $M$ ' (as for 'macaxeira') and 20 accessions of 'bitter' cassava. On similarity groups where accessions came from the same locality, they were sampled on different farms. Figure 1 shows the geographical sample locations on the map. Genomic DNA was extracted according to the method of Doyle and Doyle (1990) with modifications. Leaves were macerated with liquid nitrogen and polivinilpirrolidone and $3 \mathrm{~mL}$ CTAB extraction buffer (2\% CTAB, $5 \mathrm{M} \mathrm{NaCl}$, 0.5 M EDTA, PVP, 1 M Tris$\mathrm{HCl}$ and sterilized water) was added to the macerate. Then, it was homogenized and incubated in water bath at $65^{\circ} \mathrm{C}$ for one hour. After that period, it was added cloroformium: isoamilic alcohol (24:1), the extract was homogenized and samples were centrifuged for 10 minutes at 10,000 rpm. It was added $3 \mathrm{~mL} 95 \%$ ethylic alcohol to the supernatant to

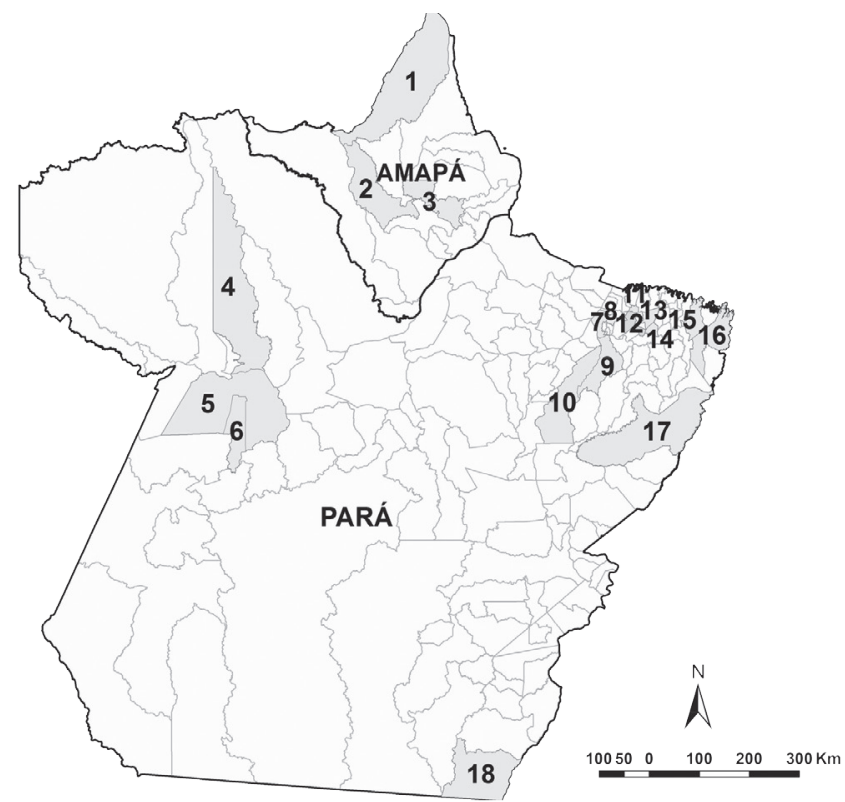

Figure 1 - Map of Pará and Amapá States showing the municipalities where cassava accessions used in this study were collected. $1=0$ iapoque; $2=$ Pedra Branca do Amapari; $3=$ Ferreira Gomes; $4=$ Alenquer; $5=$ Santarém; $6=$ Belterra; $7=$ Belém; $8=$ Santa Bárbara do Pará; $9=$ Acará; $10=$ Moju; $11=$ Terra Alta; $12=$ Castanhal; 13 = Igarapé-Açu; 14 = Santa Maria do Pará; $15=$ Bragança; 16 = Viseu; 17 = Paragominas; 18 = Santana do Araguaia. 
Table 1 - Information of places and years of cassava (Manihot esculenta) accessions used in this study from the germplasm bank of Embrapa Eastern Amazon. Letter M (as for 'macaxeira') indicates accessions of 'sweet' cassava.

\begin{tabular}{|c|c|c|c|c|}
\hline Similarity group & Germplasm bank code & Common name & Sample place in Brazil & Sample year \\
\hline \multirow{2}{*}{1} & CPATU 162 & M. Saracura-BA & Bahia State & 1995 \\
\hline & CPATU 021 & M. Saracura 2 & Unknown & 1950 \\
\hline \multirow{2}{*}{2} & CPATU 019 & M. Manteiga - PA & Mosqueiro Island, PA & 1950 \\
\hline & CPATU 183 & M. Manteiga - AP & Pedra Branca do Amapari, AP & 1996 \\
\hline \multirow{6}{*}{3} & CPATU 023 & M. Olho Preto & Unknown & 1950 \\
\hline & CPATU 147 & M. Viseu & Viseu, PA & 1994 \\
\hline & CPATU 122 & M. 25-AP & Pedra Branca do Amapari, AP & 1993 \\
\hline & CPATU 177 & M. Bahia - AP & Ferreira Gomes, AP & 1996 \\
\hline & CPATU 376 & M. Bahia - PA & Moju, PA & 2002 \\
\hline & CPATU 448 & M. Pretinha & Terra Alta, PA & 2009 \\
\hline \multirow{3}{*}{4} & CPATU 057 & M. Peruana & Alenquer, PA & 1970 \\
\hline & CPATU 009 & Hamburguesa & Unknown & 1947 \\
\hline & CPATU 366 & M. Itu & Belém, PA & 2002 \\
\hline \multirow{3}{*}{5} & CPATU 193 & Maranhense & Bragança, PA & 1996 \\
\hline & CPATU 397 & Prova D’água & Acará, PA & 2005 \\
\hline & CPATU 029 & Tapioqueira & Belém, PA & 1960 \\
\hline \multirow{4}{*}{6} & CPATU 033 & Boi 1 & Santarém, PA & 1960 \\
\hline & CPATU 317 & Boi 2 & Belterra, PA & 2001 \\
\hline & CPATU 083 & Boião 1 & Santarém, PA & 1986 \\
\hline & CPATU 305 & Boião 2 & Santarém, PA & 2001 \\
\hline \multirow{2}{*}{7} & CPATU 339 & M. Curuai & Santarém, PA & 2001 \\
\hline & CPATU 340 & M. Lulu & Santarém, PA & 2001 \\
\hline \multirow{2}{*}{8} & CPATU 255 & CAS 36.9 & Santa Bárbara, PA & 2000 \\
\hline & CPATU 143 & Maniçobeira & Belém, PA & 1994 \\
\hline \multirow{2}{*}{9} & CPATU 069 & M. Amarela 1 & Santana do Araguaia, PA & 1970 \\
\hline & CPATU 070 & M. Amarela 2 & Santana do Araguaia, PA & 1970 \\
\hline \multirow{4}{*}{10} & CPATU 261 & Pretinha & Paragominas, PA & 2000 \\
\hline & CPATU 459 & Manivão & Bragança, PA & 2009 \\
\hline & CPATU 285 & Pacajá 1 & Paragominas, PA & 2000 \\
\hline & CPATU 457 & Pacajá 2 & Bragança, PA & 2009 \\
\hline \multirow{2}{*}{11} & CPATU 498 & Milagrosa & Igarapé-Açu, PA & 2010 \\
\hline & CPATU 357 & Duquinha & Castanhal, PA & 2001 \\
\hline \multirow{2}{*}{12} & CPATU 458 & Tumase - PA & Bragança, PA & 2009 \\
\hline & CPATU 124 & Tumase - AP & Oiapoque, AP & 1993 \\
\hline \multirow{2}{*}{13} & CPATU 404 & Sebastiana & Santa Maria do Pará, PA & 2005 \\
\hline & CPATU 013 & Jurará & Belém, PA & 1947 \\
\hline
\end{tabular}

precipitate the DNA and samples were centrifuged for 10 minutes at 10,000 rpm. After that phase, the precipitate was washed with $70 \%$ ethylic alcohol for 10 minutes and at $5,000 \mathrm{rpm}$. DNA samples were ressuspended with $300 \mathrm{~mL}$ TE buffer (10 mM Tris-HCl, $1 \mathrm{mM}$ EDTA, $\mathrm{pH}$ 8.0) and RNAse. DNA was quantified in $1 \%$ agarose gel using samples of phage lambda DNA on different concentrations $(50,100$ e $200 \mathrm{ng} \mathrm{mL}^{-1}$ ) as pattern. DNA was diluted to $10 \mathrm{ng} \mathrm{mL}^{-1}$. It was used 15 microsatellite primers (Table 2), developed by Chavarriaga-Aguire et al. (1998) and Mba et al. (2001). Polymerase chain reactions (PCR) were prepared for a final volume of $20 \mathrm{~mL}$, containing $30 \mathrm{ng}$ of genomic DNA, 50
mM of each triphosphate deoxiribonucleotides (dATP, dCTP, dGTP e dTTP), $0.1 \mathrm{mM}$ of each pair of primer (forward and reverse), $10 \mathrm{mg} \mathrm{mL}^{-1}$ of BSA (bovine serum albumin), 0.6 units of Taq DNA polymerase (Invitrogen, Brazil) and $1 \mathrm{X}$ reaction buffer containing $\mathrm{MgCl}^{2}(1 \mathrm{mM})$ supplied by the manufacturer. PCR were performed on a thermocycler (Applied Byosystems, GeneAmp ${ }^{\circledR}$, PCR Instrument System 9700, USA). The temperature cycling profile was: an initial denaturation step for $5 \mathrm{~min}$ at $94^{\circ} \mathrm{C}$, followed by 30 cycles of denaturation at $94^{\circ} \mathrm{C}$ for $1 \mathrm{~min}$, annealing at $55^{\circ} \mathrm{C}$ to $59^{\circ} \mathrm{C}$ (depending on the primer) for $2 \mathrm{~min}$ and primer extension at $72^{\circ} \mathrm{C}$ for $2 \mathrm{~min}$ and a final extension cycle of $5 \mathrm{~min}$ at $72^{\circ} \mathrm{C}$. 
Table 2 - Information of microsatellite loci used in the analysis of identification of duplicates of cassava (Manihot esculenta) accessions sampled in the North region of Brazil, with respective sequence, annealing temperature, number of alleles (A), observed and expected heterozygosity $\left(\mathrm{H}_{0}\right.$ and $\left.\mathrm{H}_{\mathrm{E}}\right)$ and coefficient of endogamy $(F)$. $\mathrm{H}_{0}, \mathrm{H}^{\mathrm{E}}$ and $\mathrm{F}$ were estimated after the exclusion of duplicates.

\begin{tabular}{|c|c|c|c|c|c|c|}
\hline Locus & Sequence 5'-3' & $\mathrm{T}_{\mathrm{a}}\left({ }^{\circ} \mathrm{C}\right)$ & A & $\mathrm{H}_{0}$ & $\mathrm{H}_{\mathrm{e}}$ & $\mathrm{F}$ \\
\hline GAGG05 & $\begin{array}{l}\text { F-TAATGTCATCGTCGGCTTCG } \\
\text { R-GCTGATAGCACAGAACACAG }\end{array}$ & 55 & 2 & 0.55 & 0.44 & -0.25 \\
\hline SSRY102 & $\begin{array}{l}\text { F-TTGGCTGCTTTCACTAATGC } \\
\text { R-TTGAACACGTTGAACAACCA }\end{array}$ & 55 & 2 & 0.33 & 0.44 & 0.25 \\
\hline SSRY82 & $\begin{array}{l}\text { F-TGTGACAATTTTCAGATAGCTTCATTCA } \\
\text { R-CACCATCGGCATTAAACTTTG }\end{array}$ & 55 & 6 & 0.67 & 0.74 & 0.10 \\
\hline SSRY09 & $\begin{array}{l}\text { F-ACAATTCATCATGAGTCATCAACTAACT } \\
\text { R-CCGTTATTGTTCCTGGTCCT }\end{array}$ & 58 & 5 & 0.33 & 0.70 & 0.53 \\
\hline GA126 & $\begin{array}{l}\text { F-AGTGGAAATAAGCCATGTGATG } \\
\text { R-CCCATAATTGATGCCAGGTT }\end{array}$ & 58 & 6 & 0.50 & 0.72 & 0.31 \\
\hline GA136 & $\begin{array}{l}\text { F-CGTTGATAAAGTGGAAAGAGCA } \\
\text { R-ACTCCACTCCCGATGCTCGC }\end{array}$ & 56 & 5 & 0.67 & 0.62 & -0.07 \\
\hline SSRY04 & $\begin{array}{l}\text { F-ATAGAGCAGAAGTGCAGGCG } \\
\text { R-CTAACGCACACGACTACGGA }\end{array}$ & 55 & 8 & 0.94 & 0.80 & -0.19 \\
\hline SSRY164 & $\begin{array}{l}\text { F-TCAAACAAGAATTAGCAGAACTGG } \\
\text { R-TGAGATTTCGTAATATTCATTTCACTT }\end{array}$ & 55 & 5 & 0.28 & 0.73 & 0.62 \\
\hline SSRY20 & $\begin{array}{l}\text { F-CATTGGACTTCCTACAAATATGAAT } \\
\text { R-TGATGGAAAGTGGTTATGTCCTT }\end{array}$ & 56 & 5 & 0.50 & 0.55 & 0.09 \\
\hline SSRY19 & $\begin{array}{l}\text { F-TGTAAGGCATTCCAAGAATTATCA } \\
\text { R-TCTCCTGTGAAAAGTGCATGA }\end{array}$ & 56 & 5 & 0.83 & 0.69 & -0.20 \\
\hline SSRY63 & $\begin{array}{l}\text { F-TCAGAATCATCTACCTTGGCA } \\
\text { R-AAGACAATCATTTTGTGCTCCA }\end{array}$ & 58 & 4 & 0.44 & 0.57 & 0.22 \\
\hline SSRY106 & $\begin{array}{l}\text { F-GGAAACTGCTTGCACAAAGA } \\
\text { R-CAGCAAGACCATCACCAGTTT }\end{array}$ & 57 & 6 & 0.55 & 0.72 & 0.23 \\
\hline GA131 & $\begin{array}{l}\text { F-TTCCAGAAAGACTTCCGTTCA } \\
\text { R-CTCAACTACTGCACTGCACTC }\end{array}$ & 58 & 6 & 0.89 & 0.77 & -0.15 \\
\hline SSRY21 & $\begin{array}{l}\text { F-CCTGCCACAATATTGAAATGG } \\
\text { R-CAACAATTGGACTAAGCAGCA }\end{array}$ & 57 & 5 & 0.61 & 0.66 & 0.08 \\
\hline GA21 & $\begin{array}{l}\text { F-GGCTTCATCATGGAAAAACC } \\
\text { R-CAATGCTTTACGGGAGAGCC- }\end{array}$ & 55 & 5 & 1.00 & 0.73 & -0.37 \\
\hline Mean & & & 5 & 0.61 & 0.66 & 0.08 \\
\hline
\end{tabular}

For primer SSRY82, the conditions of amplification were: an initial denaturation step for 5 min at $94^{\circ} \mathrm{C}$, followed by 35 cycles of DNA denaturation at $95^{\circ} \mathrm{C}$ for 30 s, annealing at 55 ${ }^{\circ} \mathrm{C}$ for $30 \mathrm{~s}$ and elongation at $72^{\circ} \mathrm{C}$ for $45 \mathrm{~s}$; after 35 cycles, there was a primer extension at $72{ }^{\circ} \mathrm{C}$ for $10 \mathrm{~min}$.

Amplification products were separated on vertical electrophoresis (Omniphor, HMEDI15, England), using 6\% polyacrilamide gel. Gels were revealed with silver nitrate and scanned for image analyses. Gels were visually interpreted and each primer represented a locus and each band with different migration pattern was considered an allele. For the construction of the dendrogram, bands were analyzed as presence (1) and absence (0) for the 36 accessions. These data were used to construct a dendrogram based on the unweighted pair group method with arithmetic average (UPGMA) using the Jaccard similarity index. A bootstrap resampling method was performed to determine the robustness of the dendrogram, and 1,000 bootstrap replicates were obtained from the original data of 36 accessions. All calculations were performed using FreeTree 0.9.1.50 (Pavlicek et al. 1999) and the dendrogram was drawn using TreeView 1.6.6 (Page 2001). Genetic diversity parameters, such as the number of alleles per locus, allelic frequency, percent of polymorphic loci, observed average heterozygosity $\left(\mathrm{H}_{\mathrm{O}}\right)$, gene diversity (expected heterozygosity $-\mathrm{H}_{\mathrm{E}}$ ) obtained per locus, and allelic frequencies per locus were estimated using GenAlEx 6.4.1 (Peakall and Smouse 2006). The probability of genetic identity and the probability of exclusion were obtained according to the method suggested by Paetkau and Strobeck (1994) and calculated with GenAlEx.

\section{RESULTS}

All microsatellite loci used were $100 \%$ polymorphic and generated 75 alleles, with an average of five alleles per locus (Table 2). The number of alleles varied from two (GAGG05 and SSRY102) to eight (SSRY04). The Jaccard coefficient of similarities was estimated among cassava accessions. It was identified 34 pairs of duplicates, which showed identical multiloci profiles and, consequently, genetic similarity = 1.0. The probability that two individuals share the same genetic profile by chance with the 15 loci used and the allelic frequencies obtained was $1.1 \times 10^{-12}$. It means that the probability that they represent duplicates is $99.9999 \%$. The accessions that correspond to duplicates are listed on Table 3, with the probability of occurrence of each genotype considering the allelic frequencies estimated for the 36 accessions. All probabilities of occurrence of genotypes were very low. For genotype of group 4 (Table 3), for example, an exact match between unrelated genotypes in a randomly mating population is one in hundreds of quintillions. Considering the 13 groups of morphological similarity, only three groups had individuals that were not identical. In group 4, the genotype 'Hamburguesa' was different from 'M. Itu' and 'M. Peruana'. In group 10, 'Pretinha' and 'Manivão' were not duplicates and were different from two accessions named 'Pacajá. In group 12, the two accessions named 'Tumase' were different.

After the detection of duplicates, sample was reduced to 18 genotypes. Genetic diversity parameters were estimated after the removal of duplicates, to avoid overestimatives (Table 2). Average $H_{E}$ was 0.66 and $H_{E}$ per locus varied from 0.80 (SSRY04) to 0.44 (GAGG05 and SSRY102). Average $\mathrm{H}_{\mathrm{O}}$ was 0.61 and $\mathrm{H}_{\mathrm{O}}$ per locus varied from 1.00 (GA21) to 0.28 (SSRY164). Total coefficient of endogamy was 0.08 .

The dendrogram with bootstrap calculations clearly showed the grouping of the duplicates (Figure 2). The dendrogram showed that accessions did not cluster according to the sample location or according to 'sweet' or 'bitter' type.

The analysis showed three different situations: confirmation of materials with the same name that share the same genotype; materials with the same name that are different and genotypes with different names spread through different places. Confirmation of materials with the same name and the same 
Table 3 - Accessions of cassava (Manihot esculenta) sampled in the North region of Brazil that represented duplicates according to genotyping with 15 microsatellite loci and the probability of identity of each genotype.

\begin{tabular}{|c|c|c|}
\hline Group of similarity & Accession & Genotype probability of identity \\
\hline \multirow[t]{2}{*}{ Group 1} & M. Saracura-BA & $6.7 \times 10^{-17}$ \\
\hline & M. Saracura 2 & \\
\hline \multirow[t]{2}{*}{ Group 2} & M. Manteiga - PA & $7.9 \times 10^{-16}$ \\
\hline & M. Manteiga - AP & \\
\hline \multirow[t]{6}{*}{ Group 3} & M. Olho Preto & $5.3 \times 10^{-12}$ \\
\hline & M. Viseu & \\
\hline & M. 25-AP & \\
\hline & M. Bahia & \\
\hline & 05 M. Bahia & \\
\hline & M. Pretinha & \\
\hline \multirow[t]{2}{*}{ Group 4} & M. Peruana & $1.1 \times 10^{-15}$ \\
\hline & M. Itu & \\
\hline \multirow[t]{3}{*}{ Group 5} & Maranhense & $2.2 \times 10^{-12}$ \\
\hline & Prova D’água & \\
\hline & Tapioqueira & \\
\hline \multirow[t]{4}{*}{ Group 6} & Boi 1 & $2.4 \times 10^{-12}$ \\
\hline & Boião 1 & \\
\hline & Boi 2 & $6.1 \times 10^{-13}$ \\
\hline & Boião 2 & \\
\hline \multirow[t]{2}{*}{ Group 7} & M. Curuai & $3.1 \times 10^{-16}$ \\
\hline & M. Lulu & \\
\hline \multirow[t]{2}{*}{ Group 8} & CAS 36.9 & $4.9 \times 10^{-19}$ \\
\hline & Maniçobeira & \\
\hline \multirow[t]{2}{*}{ Group 9} & M. Amarela 1 & $1.1 \times 10^{-13}$ \\
\hline & M. Amarela 2 & \\
\hline \multirow[t]{2}{*}{ Group 10} & Pacajá 1 & $3.0 \times 10^{-14}$ \\
\hline & Pacajá 2 & \\
\hline \multirow[t]{2}{*}{ Group 11} & Milagrosa & $2.2 \times 10^{-15}$ \\
\hline & Duquinha & \\
\hline \multirow[t]{2}{*}{ Group 13} & Sebastiana & $2.0 \times 10^{-12}$ \\
\hline & Jurará & \\
\hline
\end{tabular}

genotype occurred even for accessions sampled in different places. Among the genotypes identified as duplicates, there are accessions sampled in very distant periods, such as genotypes 'Sebastiana', sampled in 2005, and 'Jurará, sampled in 1947 , both in Pará State (Table 1). This situation occurs for the duplicates of groups 1, 2, 3, 4, 5, 6 and 13 (Table 1). Also, the same genotype was sampled in different places in groups $2,3,4,5,6,8,10,11$ and 13 .

\section{DISCUSSION}

We have shown in this study that some cassava genotypes are spread through a large area in the North region, more than $99.9999 \%$ confident. The sample size could be considered small to estimate the allelic frequencies, which could lead to an underestimation. However, the $\mathrm{H}_{\mathrm{E}}$ (Table 2) obtained were similar to the ones obtained in other analyses done with a higher number of samples, when primers GA21, GA126,
GA131 and GA136 were compared (Elias et al. 2001; Siqueira et al. 2009; Siqueira et al. 2010).

$\mathrm{H}_{\mathrm{O}}$ values, although high, were comparable to the values obtained with cassava sampled in several parts of the world (Elias et al. 2001; Fregene et al. 2003). High levels of heterozygosis are characteristic of a plant with allogamous reproduction and asexual propagation.

The occurrence of the same genotypes in different places confirms the existence of exchanges of propagative material of cassava genotypes among farmers in the North region. This may have contributed to the lack of correlation between genetic grouping in the dendrogram and geographical places, as observed for cassava in other geographic regions (Elias et al. 2004; Siqueira et al. 2009). The different denominations that farmers attribute to cassava landraces seem to be common. Surveys of cassava names in different countries have identified that the nomination of the landraces is often given separately by farmers, even from the same place or community (Salick $e t$ al. 1997; Mkumbira et al. 2003). However, there were varieties that kept their names over the years and in different places, such as 'Pacajá', 'M. Manteiga' and 'M. Saracura'. This may

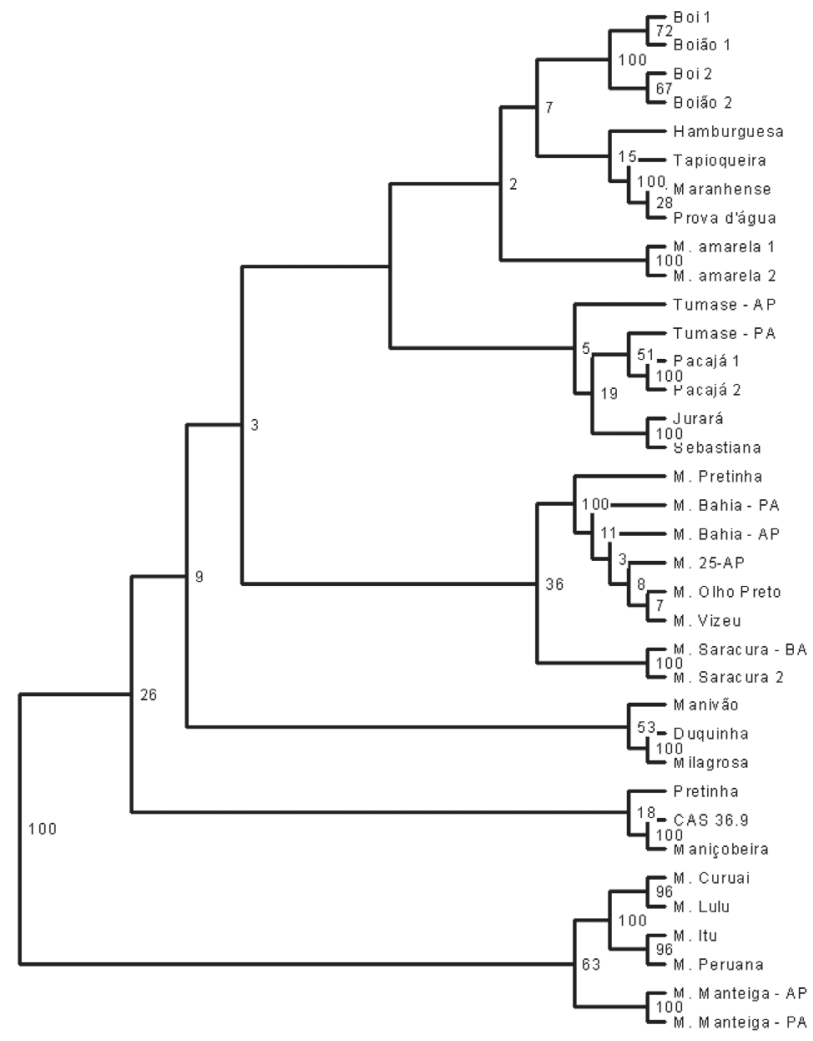

Figure 2 - Dendrogram of the 36 accessions of cassava (Manihot esculenta) obtained from 15 microsatellite markers polymorphism using the similarity index of Jaccard, bootstrap values and the unweighted pair group method with arithmetic mean (UPGMA). 
be related to the importance and value of the landrace among farmers of a more extensive area. Otherwise, the accessions named 'Tumase' were very genetically different, evidencing another common situation among cassava landraces: the coincidence of names between genetically distinct genotypes.

The identification of duplicates on germplasm banks of vegetatively propagated plants seems to be common (Irish $e t$ al. 2010; van Treuren et al. 2010). This may be due to usual exchanges of propagules among farmers of different regions, especially when the species has economical importance. In the new place, that genotype may receive a new name, causing certain confusion on samples and maintenance of accessions on germplasm banks. However, as the species are vegetatively propagated, there may be spontaneous mutations in a single gene that generates an interesting variation. Thus, although genotyping with molecular markers can identify duplicates, the accessions genetically identical may not be discarded immediately, not before characterization is complete. Chemical characterization and analysis of genotypes resistance/tolerance to diseases may reveal differences among individuals with the same multiloci profile that may be due to a single mutation. However, duplicates identification is important to cluster accessions and to avoid crossings between them.

This study showed the occurrence of duplicates in a cassava germplasm bank composed mainly of landraces sampled on the North region of Brazil and evidenced specific genotypes that are spread through different sites of the region. The identification of these duplicates will be useful to the germplasm bank management and also in the selection of accessions for field trial experiments.

The resampling of the same genotype over many years in different places of the North region of Brazil may reflect the importance that some genotypes have for the farmers. These genotypes may be the most productive or have an important characteristic for food. Also, it emphasizes the importance that local farmers have as keepers of the genetic variation of cassava.

\section{CONCLUSIONS}

The study showed that the availability of polymorphic microsatellite loci for cassava allowed identification of duplicates in a germplasm bank composed of accessions sampled mainly in the North region of Brazil. Identification of duplicates was $99.9999 \%$ confident. It showed that molecular characterization with highly informative markers is important to determine duplications in germplasm banks of vegetatively propagated species, such as cassava, and to reduce numbers of accessions in the bank, helping in its management. It also showed the great dispersion that some genotypes of cassava have in the North region, confirming that local farmers are keepers of genetic variability of cassava.

\section{ACKNOWLEDGMENTS}

The authors thank FAPESPA, CNPq and Embrapa for financial support and scholarship grants.

\section{REFERENCES}

Chavarriaga-Aguirre, P.P.; Maya, M.M.; Bonierbale, M.W.; Kresovich, S.; Fregene, M.A.; Tohme. J.; Kochert, G. 1998. Microsatellites in cassava (Manihot esculenta Crantz): discovery, inheritance and variability. Theoretical and Applied Genetics, 97: 493-501.

Doyle, J.J.; Doyle, J.L. 1990. Isolation of plant DNA from fresh tissue. Focus, 12: 13-15.

Elias, M.; Muhlen, G.S.; McKey, D.; Roa, A.C.; Tohme, J. 2004. Genetic diversity of traditional South American landraces of cassava (Manihot esculenta Crantz): an analysis using microsatellites. Economic Botany, 52: 242-25.

Elias, M.; Penet, L.; Vindry, P.; McKey, D.; Panaud, O.; Robert, T. 2001. Unmanaged sexual reproduction and the dynamics of genetic diversity of a vegetatively propagated crop plant, cassava (Manihot esculenta Crantz) in a traditional farming system. Molecular Ecology, 10: 1895-1907.

Fregene, M.; Suarez, M.; Mkumbira, J.; Kulembeka, H.; Ndedya, E.; Kulaya, A.; Mitchel, S.; Gullberg, U.; Rosling, H.; Dixon, A.G.O.; Dean, R.; Kresovich, S. 2003. Simple sequence repeat marker diversity in cassava landraces: genetic diversity and differentiation in an asexually propagated crop. Theoretical and Applied Genetics, 107:1083-1093.

Fukuda, W.M.G.; Guevara, C.L. 1998. Descritores morfológicos e agronômicos para a caracterização de mandioca (Manihot esculenta Crantz). Embrapa, Cruz das Almas, BA, Brasil. 38p.

Irish, B.M.; Goenaga, R.; Zhang, D.; Schnell, R.; Brown, J.S.; Motamayor, J.C. 2010. Microsatellite fingerprinting of the USDA-ARS tropical agriculture research station cacao (Theobroma cacao L) germplasm collection. Crop Science, 50: 656-667.

Léotard, G.; Duputié, A.; Kjellberg, F.; Douzery, E.J.P.; Debain, C.; Granville, J.J.; McKey, D. 2009. Phylogeography and the origin of cassava: new insights from the Northern rim of the Amazonian basin. Molecular Phylogenetics and Evolution, 53: 329-334.

Mba, R.E.C.; Stephenson, P.; Edwards, K.; Melzer, S.; Nkumbira, J.; Gullberg; U.; Ape, K.; Gale, M.; Tohme, J.; Fregene, M. 2001. Simple sequence repeats (SSR) markers survey of the cassava (Manihot esculenta Crantz) genome: towards an SSRbased molecular genetic map. Theoretical and Applied Genetics, 102: 21-31.

Mkumbira, J.; Chiwona-Karltun, L.; Lagercrantz, U.; Mahungu, N.M.; Saka, J.; Mhone, A.; Bokanga, M.; Brimer, L.; Gullberg, U.; Roling, H. 2003. Classification of cassava into 'bitter' and 'cool' in Malawi: from farmers perception to characterization by molecular markers. Euphytica, 132: 7-22.

Olsen, K.M.; Schaal, B.A. 2001. Microsatellite variation in cassava (Manihot esculenta, Euphorbiaceae) and its wild relatives: further evidence for a Southern Amazonian origin of domestication. American Journal of Botany, 88:131-142. 
Page, R.D.M. TreeView. Version 1.6.6. Glasgow: University of Glasgow, 2001. (http://taxonomy.zoology.gla.ac.uk/rod/ treeview/treeview_manual.html) Accessed on: 11/01/2013.

Pavlícek, A.; Hrdá, S.; Flegr, J. 1999. FreeTree - freeware program for construction of phylogenetic trees on the basis of distance data and bootstrap/jackknife analysis of the tree robustness. Application in the RAPD analysis of genus Frenkelia. Folia Biologica 45: 97-99.

Paetkau, D.; Strobeck, C. 1994. Microsatellite analysis of genetic variation in black bear populations. Molecular Ecology 3: 489-495.

Peakall, R.; Smouse, P.E. 2006. GENALEX 6: genetic analysis in excel. Population genetic software for teaching and research. Molecular Ecology Notes 6:288-295.

Robichaud, R.; Glaubitz, J.C.; Rhodes Jr., O.E.; Woeste, K. 2006. A robust set of black walnut microsatellites for parentage and clonal identification. New Forests, 32: 179-196.
Salick, J.; Cellinese, N.; Knapp, S. 1997. Indigenous diversity of cassava: generation, maintenance, use and loss among the Amuesha, Peruvian upper Amazon. Economic Botany, 51:7-17.

Siqueira, M.V.B.M.; Queiroz-Silva, J.R.; Bressan, E.A.; Borges, A.; Pereira, K.J.C.; Pinto, J.G.; Veasey, E.A. 2009. Genetic characterization of cassava (Manihot esculenta) landraces in Brazil assessed with simple sequence repeats. Genetics and Molecular Biology, 32: 104-110.

Siqueira, M.V.B.M.; Pinheiro, T.T.; Borges, A.; Valle, T.L.; Zatarim, M.; Veasey, E.A. 2010. Microsatellite polymorphisms in cassava landraces from the Cerrado Biome, Mato Grosso do Sul, Brazil. Biochemical Genetics, 48: 879-895.

Van Treuren, R.; Kemp, H.; Ernsting, G.; Jongejans, B.; Houtman, H.; Visser, L. 2010. Microsatellite genotyping of apple (Malus $x$ domestica Borkh) genetic resources in the Netherlands: application in collection management and variety identification. Genetic Resources and Crop Evolution, 57: 853-865.

Recebido em: 25/06/2012

Aceito em: 04/02/2013 
